\title{
Avaliação no Estágio Supervisionado: intersubjetividades na formação de professores em cursos na modalidade EAD
}

\author{
Eliana Rela \\ Orientadora: Marie Jane Soares Carvalho \\ Coorientadora: Magda Bercht \\ Data da defesa: $27 / 09 / 2010$
}

O estudo da presente pesquisa propõe inserir novos horizontes, justificados cientificamente, sobre avaliação no estágio supervisionado, com novas bases metodológicas, novas concepções e, chegar a uma nova cultura da avaliação, isto é, uma cultura circular da avaliação em processos de estágio curricular supervisionado. Apoia-se em considerações e reflexões sobre a intersubjetividade e a construção social das lógicas de avaliação no estágio de professores em formação continuada, em contextos tecnológicos de cursos de Licenciatura em Pedagogia de duas universidades, sendo uma privada e outra pública. O estudo parte da premissa de que os ambientes digitais para aprendizagem são domínios de convivência, isto é, uma estrutura na qual é possível um sistema de ações onde se dá a comunicação e a aprendizagem. As ações e o movimento intersubjetivo, dos diferentes atores envolvidos no processo de avaliação das competências desenvolvidas no estágio, são discutidos a partir da análise da comunicação que ocorre em tal contexto de ação, da linguagem como expressão da intersubjetividade para si e para o outro. A investigação procurou analisar o processo de mediação profissional, com base em uma reconceituação da supervisão de estágio e da dimensão da avaliação, como parte do processo sistemático e dinâmico da reconstrução social, de concepções e experiências educativas, em níveis diversos de constituição profissional. Procurou também avaliar a proposta de balanço de competências em situação de estágio de docência, originariamente concebida pelo grupo de professores orientadores de estágio do curso de Licenciatura em Pedagogia - modalidade EaD - da Universidade de Caxias do Sul, e aplicada, ampliada e aprofundada pela equipe de professores orientadores de estágio do curso de Licenciatura em Pedagogia - modalidade EaD - Universidade Federal do Rio Grande do Sul. A elaboração de conhecimentos, na formação docente, constitui-se como uma produção que ocorre na dinâmica interativa das relações sociais, envolvendo a linguagem e o funcionamento interpessoal, sendo historicamente situado e suscetível de novos processos de (re)construção. Esse pensamento é sustentado em Bateson (2008), que o explicita dizendo que o sujeito, ao realizar distinções, constrói o mundo, como uma maneira de conhecê-lo e, também, como forma de conhecer seu conhecer. Assim, o conhecimento é construído de forma relacional e no terreno da intersubjetividade. A questão de pesquisa é: Como supervisores e estagiários vivem, percebem e concebem a avaliação da práxis no estágio de professores em formação continuada de dois cursos de pedagogia, na modalidade a distância, cujas interações são mediadas com o apoio de ambiente virtual de aprendizagem? Os procedimentos metodológicos de construção e análise qualitativa de dados abrangem: (a) os registros das mediações realizadas por oito supervisores de estágio no acompanhamento, na orientação e avaliação de estágio; (b) as produções de 144 professores experientes em situação de estágio curricular; (c) pareceres de autoavaliação. O tempo de docência dos professores em situação de estágio varia no intervalo entre um mínimo de quatro anos e o máximo de 32 anos. Atuam em diferentes municípios do Estado do Rio Grande do Sul, com multiplicidade de contextos culturais. As propostas de avaliação estudadas foram desenvolvidas no penúltimo semestre dos respectivos cursos. A Instituição 1 iniciou os estágios a partir do segundo ano de curso, com a carga horária distribuída ao longo de três módulos. A Instituição 2 optou por realizar o estágio concentrado em um único semestre. O processo comunicativo registrado na vida cotidiana da avaliação e da supervisão de estágio é aqui compreendido como realidade social, possibilitando à investigação o caráter de pesquisa-ação, tomando como referencial teórico a fenomenologia do sociólogo Alfred Schütz (2003) sobre intersubjetividade, cotidiano e realidade. A partir da discussão dos resultados, emergem algumas linhas-guias do novo papel da supervisão e da dimensão 
da avaliação, no estágio de professores em formação continuada, apoiada em AVA, relacionando a maior eficácia do modelo, com base na intersubjetividade, à formação de competências. Há evidências de que mediações com atitudes de questionamento potencializam processos de problematização e construção de competências, promovendo uma avaliação mediadora no processo. Entre as linhas-guias está a arquitetura proposta para o ambiente virtual de aprendizagem, como espaço de relações; a construção de processos comunicativos identificadores da realidade social do outro sujeito, seu mundo da vida cotidiana e o universo de significados culturais historicamente situados; as produções de autoria como o diário, o portfólio e as sínteses reflexivas.

Palavras-chave: Avaliação. Estágio. Intersubjetividade. Supervisão. Competências. 